ring in Llao Llao population, but we cannot generalize such observation to all of the populations of the species.

Indirect methods, like HW test, suffer from the shortcoming of being based on too many assumptions, which can hardly be controlled in order to test them separately. Direct procedures of testing any kind of genetic processes should always be preferred. Otherwise, conclusions could be no more than speculation based on mathematical models not well adjusted to the real biological processes.

\section{Acknowledgements}

Elizabeth Gillet, from Institut für Forstgenetik und Forstpflanzenzüchtung, Göttingen University, is acknowledged for the use of her unpublished program exacttst. Support for the first author was provided by a doctoral fellowship from Deutscher Akademischer Austauschdienst (DAAD), and a grant from Fundación Antorchas. The help of the Delegación Técnica Regional Patagonia from Administración de Parques Nacionales (APN) is appreciated for their essential general support. We also thank an anonymous reviewer's valuable comments.

\section{References}

Brion, C., D. GRigera and P. Rosso (1993): The reproduction of Austrocedrus chilensis (D. DoN) Florin et Boutelje. C R Acad Sci Paris, Sciences de la vie 316: 721-724.

Castor, C., J. G. Cuevas, M. T. Kalin Arroyo, Z. Raffi, R. DodD and A. PeÑalosa (1996): Austrocedrus chilensis (D. Don) Pic.-Ser. et Bizz. (Cupressaceae) from Chile and Argentina: monoecious or dioecious? Rev. Chil. Hist. Nat. 69: 89-95.

ChoI, W. Y., K. S. KANG, K. W. JANG, S. U. HAN and C. S. KIM (2004): Sexual asymmetry based on flowering assessment in a clonal seed orchard of Pinus densiflora. Silvae Genet. 53: $55-59$.
Gallo, L. A. and Th. Geburek (1994): A short note: genetics of enzyme variants in Austrocedrus chilensis (Engl.) Florin et Boutelje. Phyton 34: 103-107.

GILLET, E. (1997): GSED Genetic Structures from Electrophoresis Data, version 1.1d, program and user's manual. Institut für Forstgenetik und Forstpflanzenzüchtung, Faculty of Forest Genetics and Forest Ecology, University of Göttingen, URL: http://www.uni-forst.gwdg.de/forst/fg/index.htm.

MÜLLER, G. (1976): A simple method of estimating rates of selffertilization by analyzing isozymes in tree seeds. Silvae Genet. 25: 15-17.

Pastorino, M. J. and L. A. Gallo (1998): Inheritance of isozyme variants in Austrocedrus chilensis (D. DoN) Florin et Boutelje. Silvae Genet. 47: 15-20.

PASTORINO, M. J. and L. A. GALLO (2001): Linkage relationships as a useful tool to state interspecific gene homology: Case study with isozyme loci in Austrocedrus chilensis (Cupressaceae). Silvae Genet. 50: 233-239.

PASTORINo, M. J. and L. A. GALlo: Spatial structure of mating in a low-density natural population of the dioecious wind-pollinated Patagonian Cypress. Genetica (accepted).

Purser, A. F. (1966): Increase in heterozygote frequency with differential fertility. Heredity 21: 322-347.

SoKAL, R. R. and F. J. RoHLF (1981): Biometry: the Principles and Practice of Statistics in Biological Research. Freeman, $2^{\text {nd }}$ ed., San Francisco.

WALLACE, B. (1958): The comparison of observed and calculated zygotic distributions. Evolution 12: 113-115.

ZIEHE, M. and H.-R. GREGORIUS (1981): Deviations of genotypic structures from Hardy-Weinberg proportions under random mating and differential selection between the sexes. Genetics 98: $215-230$.

Ziehe, M. and H. H. HatTemer (1985): Neuere Erkenntnisse über Asymmetrie-Effekte in der sexuellen Reproduktion von Waldbäumen. Allg. Forst- u. J. Ztg. 156: 225-231.

\title{
PCR-Multiplex of Six Chloroplast Microsatellites for Population Studies and Genetic Typing in Pinus sylvestris
}

\author{
By A. Dzialuk and J. BurczyK
}

Department of Genetics, Institute of Biology and Environmental Protection, Bydgoszcz University, 85-064 Bydgoszcz, Poland e-mail: dzialuk@ab-byd.edu.pl; burczyk@ab-byd.edu.pl

(Received 19 ${ }^{\text {th }}$ August 2004)

\begin{abstract}
The major drawback of microsatellites analysis is that they are expensive to develop, labor-intensive and demand skilled personnel. However, such studies might be still simplified and accelerated by multiplexing of the markers and the use of highthroughput systems for genotyping DNA fragments. In this paper we present a single, simple and highly effective PCRmultiplex reaction composed of six chloroplast microsatellites widely used for population studies in pines but here applied to Pinus sylvestris. The reaction allows for rapid genotyping of large sample sizes.
\end{abstract}

Key words: chloroplast microsatellites; PCR-multiplex, Pinus sylvestris; polymorphism; haplotypes.

\section{Introduction}

The set of microsatellites for Pinus species has been developed by Vendramin et al. (1996) and Provan et al. (1998). Since then, the chloroplast microsatellites have become an efficient and powerful marker for studying genetic diversity and differentiation among conifers (ECHT et al., 1998; GugerLI et al., 2001; WALTER and EPPERSON, 2001). They also have proved to be useful for measuring pollen contamination in seed orchards (Plomion et al., 2001), or for the identification of the origin of populations with uncertain history (RIBEIRO et al., 2002).

The availability of high-throughput systems for genotyping DNA fragments (automated sequencers) involving multicolor 
fluorescent fragment labeling allows for simultaneous analyses of several markers increasing the efficiency of genotyping of large samples, which are typical in population genetic studies. Multiplex PCRs (simultaneous amplification of two or more loci in a single PCR reaction) are common in microbial diagnostics, animal breeding and recently become popular among agricultural crops (TANG et al., 2003, and references therein). Nevertheless, PCR multiplexes were seldom reported for conifers (Bousquet and Perry, 2000; Marshall et al., 2002; Stoehr and NEwTon, 2002). Although some authors report the postPCR multiplexing (pooling) of two or more individually amplified PCR products, and use of the aliquots in a single electrophoresis run (VENDRAMIN et al., 1996; ECHT et al., 1998; WALTER and EPPERSON, 2001), the PCR-multiplexing offers an advantage of reducing time and costs of analyses (NEFF et al., 2000; TANG et al., 2003). The aim of this study was to develop simple (i.e., standardized composition of the PCR reaction as well as standard thermal cycle profile) and highly effective PCR reaction for rapid genotyping of large sample sizes.

Twenty nine individuals representing different clones of Scots pine (Pinus sylvestris L.) were sampled from a seed orchard located in Gniewkowo, Poland. Genomic DNA was isolated from $100 \mathrm{mg}$ of frozen needles and additional, for ten randomly chosen trees, from diploid embryos of germinated seed (seedlings $5-10 \mathrm{~mm}$ in length) and from haploid megagametophytes. Three different methods of isolation were used: DNeasy Plant Mini Kit (Qiagen) according to the manufacturer's instructions, Dellaporta et al. (1983) and Doyle and Doyle (1990) protocols. Concentration of DNA samples was measured using DNA calculator (BioPhotometr, Eppendorf).

Multiplex PCRs were performed in $10 \mu \mathrm{l}$ reaction mixture using a thermocycler (PTC-200, MJ Research). The microsatellites selected to combine in a single multiplex were: Pt15169, Pt26081, Pt30204, Pt36480, Pt71936 (VEndramin et al., 1996), and PCP87314 (Provan et al., 1998). The forward primer of each microsatellite was labeled with a specific fluorescent dye (Applera), as indicated in Table 1. The final optimal reaction mixture, derived based on the results of several experiments where different concentrations of components were tested, contained $20 \mathrm{ng}$ of template DNA, 1x PCR buffer (10 mM TRIS$\mathrm{HCl}, 50 \mathrm{mM} \mathrm{KCl}$; Sigma), $3 \mathrm{mM}$ of $\mathrm{MgCl}_{2}, 0.2 \mathrm{mM}$ of each dNTP, 0.04-0.15 $\mu \mathrm{M}$ each of forward and reverse primers (see below and table 1), $0.4 \mu \mathrm{g} / \mu \mathrm{l}$ of BSA, and $0.25 \mathrm{U}$ of REDTaq Genomic DNA Polymerase (Sigma). The PCR conditions were as follows: after initial denaturation at $94^{\circ} \mathrm{C}$ for $5 \mathrm{~min}$, PCR was performed for 30 cycles, each consisting of $94^{\circ} \mathrm{C}$ for $30 \mathrm{~s}$, $50^{\circ} \mathrm{C}$ for $1 \mathrm{~min}$ and $72^{\circ} \mathrm{C}$ for $1 \mathrm{~min}$. Final extension was at $72^{\circ} \mathrm{C}$ for $10 \mathrm{~min}$. PCR products $(1 \mu \mathrm{l})$ were mixed with $9 \mu \mathrm{l}$ of FSS (formamided size standard - HD 400 ROX Size Standard (Applera): formamide, in ratio 1:24). Microsatellite fragments

Table 1. - Characterization of six multiplexed chloroplast microsatellites used in a PCR-multiplex.

\begin{tabular}{cccccc}
\hline Locus & $\begin{array}{c}\text { Fluorescent } \\
\text { dye }\end{array}$ & $\begin{array}{c}\text { Primer } \\
\text { concentrations }\end{array}$ & $\begin{array}{c}\text { Expected } \\
\text { product size }\end{array}$ & $\begin{array}{c}\text { Observed } \\
\text { product size }\end{array}$ & $\begin{array}{c}\text { Number of } \\
\text { alleles }\end{array}$ \\
\hline PCP87314 & HEX & $40 \mathrm{nM}$ & $114-118^{\text {b }}$ & $111-114$ & 4 \\
Pt 26081 & FAM & $50 \mathrm{nM}$ & $109-112^{\text {a }}$ & $104-105$ & 2 \\
Pt 15169 & NED & $75 \mathrm{nM}$ & $124-128^{\text {a }}$ & $122-126$ & 5 \\
Pt 30204 & NED & $100 \mathrm{nM}$ & $141-146^{\text {a }}$ & $140-144$ & 5 \\
Pt 36480 & FAM & $150 \mathrm{nM}$ & $143-144^{\text {a }}$ & $140-141$ & 2 \\
Pt 71936 & HEX & $75 \mathrm{nM}$ & $141-148^{\text {a }}$ & $143-146$ & 4 \\
\hline
\end{tabular}

a from RoBledo et al. (2004)

b from PROvan et al. (1998) were analyzed on ABI Prism 310 DNA Sequencer (Applera). The actual sizes of fragments were determined using GeneScan and Genotyper software packages (Applera) using internal standards. For simplicity, in this paper the term "locus" will refer to a cpSSR site, while "allele" will refer to a size variant of a cpSSR site (EcHT et al., 1998). Since the chloroplast genome does not recombine, a combination of alleles across loci can be considered a haplotype.

The optimal conditions for multiplex PCR were determined also by altering primer concentration. Primers were initially evaluated by using equimolar concentrations of all primer pairs (150 nM) in individual PCR and analyzed for product size and yields. Next, the multiplex-PCR product yields were used to adjust the concentration of the primer pairs, to give comparable results within the reaction. Concentrations were altered for one primer pair at a time, increased when intensity of the corresponding product was to low, and decreased when intensity of the product was too high. After few primer optimization steps, the final concentration has been determined, that gives comparable yields from each individual primer pair (about 1000 relative fluorescence intensity units). Using the primer ratios determined by sequential optimization, there was no need for further optimizations (e.g. change the other PCR conditions).

Different strategies of DNA extraction resulting in different template qualities may play a crucial role in the efficiency of PCR reaction. We found the same results using different methods of DNA extraction, but it should be noted, that without BSA, the reaction for some individual trees (especially using Qiagen's kit) did not work at all. The best results were obtained when using above mentioned adjuvant at higher concentration than previously reported (e.g. $0,2 \mathrm{mg} / \mu \mathrm{l}$ in PALME et al., 2004). Such high BSA concentration guarantees successful multiplex PCR amplification, apart from template quality.

The optimized PCR multiplex worked well for the various tissues sampled (needles, seed megagametophytes and embryos). The multiplex PCR reaction was successfully used even for single megagametophytes, while some authors reported problems using templates prepared from this type of tissue (BOUSQUeT and PERrY, 2000).

Among 29 individuals of Scots pine, the number of alleles per locus ranged from 2 to 5 . There were 24 unique haplotypes, however the smaller number of haplotypes than the number of sampled clones (29) may be the result of ramet mislabeling during the seed orchard establishment, which was suspected after our previous isozyme study of that orchard (BURCZYK et al., 2000). An alternative explanation is just that different clones are sharing the same chloroplast haplotypes, either because of shared paternal ancestry or because of lack of marker resolution. More detailed verification of all orchard ramets seems to be necessary in the future.

Because fragment sizes of some of the studied loci do not overlap, a subset of loci included in our multiplex can be used even in non-multicolor labeling DNA fragment analyzers. On the other hand, because the multiplex reaction is highly efficient, multicolor fluorescent labeling may allow to include some additional loci. Nevertheless, the selection of additional loci needs to be careful. Despite that the cpSSR markers proposed by PROVAN et al. (1998) have different primer pairs than those developed by VENDRAMIN et al. (1996), they actually amplify the same microsatellite regions. The primer code denotes the position of the 5' base of sense forward primer in the published P. thunbergii cp DNA sequence (VENDRAMIN et al., 1996) and therefore e.g. PCP30277 = Pt30204; PCP71987 = Pt71936. In 
our study, the replacement of Vendramin's primer pair Pt87268 by Provan's PCP87314, enabled us to multiplex a set of six chloroplast microsatellites. Such strategy may be also useful to design multiplex reactions even for non-multicolor sequencers.

The high number of chloroplast haplotypes typical in pines (Plomion et al., 2001; RoBledo et al., 2004; this study), despite population genetic studies, can also be used in genetic typing surveys, including forestry management practices or even forensics (WHite et al., 2000). For example, if the cpSSR profiles of a number of elite mother trees used for commercial seed collections are known, the assay of a sample of seed megagametophytes may verify the origin of the seeds. Also, clonal identification of ramets in clonal seed orchards may be achieved with a greater reliability. This type of investigation will certainly be simplified by the aid of the presented multiplex. We expect that the multiplex optimized in this paper for Pinus sylvestris can be effectively used in other pine species.

\section{Acknowledgements}

We thank G. G. Vendramin and J. J. Robledo for helpful comments and suggestions on earlier draft. The technical assistance of Magdalena Wasielewska and Malgorzata Peplinska is greatly acknowledged.

\section{References}

Burczyk, J., Dzialuk, A. and Lewandowski, A. (2000): Genetic variation of Scots pine (Pinus sylvestris L.) in Gniewkowo clonal seed orchard. Sylwan 7: 65-73 [In Polish].

Bousquet, J. and PerRy, D. J. (2000): Genetic diversity of black spruce populations regenerated after fire or after harvest with pre-established regeneration protection. Project Report 2000-24. Sustainable Forest Management Network. Universite Laval.

Dellaporta, S. L., Wood, J. and Hicks, J. B. (1983): A plant DNA minipreparation: Version II. Plant Molecular Biology Repoter 1: 19-21.

Doyle, J. J. and Doyle, J. L. (1990): Isolation of plant DNA from plant tissue. Focus 12: 13-15.

Echt, C. S., Deverno, L. L., Anzidei, M. and Vendramin, G. G. (1998): Chloroplast microsatellites reveal population genetic diversity in red pine, Pinus resinosa Ait. Molecular. Ecology 7: 307-316.

Gugerli, F., Senn, J., Anzidei, M., Madaghiele, A., Buchler, U., Sperisen, C. and Vendramin, G. G. (2001): Chloroplast microsatellites and mitochondrial nad1 intron 2 sequences indicate congruent phylogenetic relationships among Swiss stone pine (Pinus cembra), Siberian stone pine (Pinus sibiri$c a$ ), and Siberian dwarf pine (Pinus pumila). Molecular Ecology 10: 1489-1497.
Marshall, H. D., Newton, C., and Ritland, K. (2002): Chloroplast phylogoegraphy and evolution of highly polymorphic microsatellites in lodgepole pine (Pinus contorta). Thoretical and Applied Genetics 104: 367-378.

NeFF, B. D., FU, P. and Gross, M. R. (2000): Microsatellite multiplexing in fish. Transactions of the American Fisheries Society 129: 584-593.

Palme, A. E., Su, Q., Palsson, S. and Lascoux, M. (2004): Extensive sharing of chloroplast haplotypes among European birches indicates hybridization among Betula pendula, B. pubescens and B. nana. Molecular Ecology 13: 167-178.

Plomion, C., Leprovost, G., Pot, D., Vendramin, G. G., Gerber, S., Decroocq, S., Brach, J., Raffin, A. and PastuszKA, P. (2001): Pollen contamination in a maritime pine polycross seed orchard and certification of improved seeds using chloroplast microsatellites. Canadian Journal of Forest Research 31: 1816-1825.

Provan, J., Soranzo, N., Wilson, N. J., McNicol, J. W., ForRest, G. I., Cottrell, J. and Powell, W. (1998): Gene-pool variation in Caledonian and European Scots pine (Pinus sylvestris L.) revealed by chloroplast simple-sequence repeats. Proceedings of the Royal Society of London. Series B, Biological Sciences 265: 1697-1705.

Ribeiro, M. M., Leprevost, G., Gerber, S., Vendramin, G. G., Anzidei, M., Decroocq, S., Marpeau, A., Mariette, S. and Plomion, C. (2002): Origin identification of maritime pine stands in France using chloroplast simple-sequence repeats. Annals of Forest Sciences 59: 53-62.

RoBledo, J. J., AliA, R. and GIL, L. (2004): High levels of genetic diversity in a long-term European glacial refugium of Pinus sylvestris L. In: Paule, L., Vendramin, G. G., Gomory, D. (eds.). Population and Evolutionary Genetics of Forest Trees. Arbora Publishers, Zvolen, Slovakia (in press).

Stoenr, M. U. and Newton, C. (2002): Evaluation of mating dynamics and pollen contamination in a lodgepole pine seed orchard using chloroplast DNA markers. Canadian Journal of Forest Research 32: 469-476.

TANG, S. X., KISHORE, V. K. and KNAPP, S. J. (2003): PCR-multiplexes for a genome-wide framework of simple sequence repeat marker loci in cultivated sunflower. Theoretical and Applied Genetics 107: 6-19.

Vendramin, G. G., Lelli, L., Rossi, P. and Morgante, M. (1996): A set of primers for the amplification of 20 chloroplast microsatellites in Pinaceae. Molecular Ecology 5: 595-598.

WALter, R. and EPPERSON, B. K. (2001): Geographic pattern of genetic variation in Pinus resinosa: area of greatest diversity is not the origin of postglacial populations. Molecular Ecology 10: $103-111$.

White, E., Hunter, J., Dubetz, C., Brost, R., Bratton, A., EdEs, S. and SAHOTA, R. (2000): Microsatellite markers for individual tree genotyping: application in forest crime prosecutions. Journal of Chemical Technology and Biotechnology 75: 923-926. 